\title{
Paediatric care standards among wards in Poland from the perspective of staff, patients, and parents with particular emphasis on psychological care
}

\author{
Standard opieki pediatrycznej na oddziałach dziecięcych w Polsce z perspektywy \\ personelu, pacjentów oraz rodziców ze szczególnym uwzględnieniem opieki \\ psychologicznej
}

\author{
Michał Smoczok¹, Krzysztof K. Starszak², Weronika Starszak ${ }^{3}$ \\ ${ }^{1}$ Department of Biophysics, Faculty of Medical Sciences in Zabrze, Medical University of Silesia, Katowice, Poland \\ Head of the Department: Sławomir Grzegorczyn PhD; \\ Head of the Students' Scientific Society: Prof. Zbigniew Nawrat PhD \\ ${ }^{2}$ Department of Orthopaedics, Faculty of Medical Sciences in Zabrze, Medical University of Silesia, Katowice, Poland \\ Head of the Department: Maciej Wrotniak PhD \\ 'Students' Scientific Society, Department of Pediatrics, Faculty of Medical Sciences in Zabrze, Medical University of Silesia, Katowice, Poland \\ Head of the Society: Jarosław Kwiecień MD, PhD
}

Key words: paediatrics, mental health, hospital care, long-term treatment, psychology in paediatrics.

Słowa kluczowe: pediatria, zdrowie psychiczne, opieka szpitalna, opieka długoterminowa, psychologia w pediatrii.

\begin{abstract}
Introduction: During hospitalisation, the child is in an unknown environment that is associated with unpleasantness, fear, and pain. Constant progress has been made in the area of improving the mental comfort of treated children by adjusting the appearance of facilities, increasing the availability of psychologists, and educating parents and patients.

Aim of the research: To summarise the perspective of three entities - staff, parents, and children in the context of hospitalisation of paediatric patients with a specification of psychological care.

Material and methods: A survey consisting of 12 questions was conducted among 405 respondents divided into three study groups and three subgroups in the group of children. The study was conducted in paediatric wards with varying degrees of reference in Poland. Material was subjected to statistical analysis.

Results: The most common answer in all groups was that children respond to information about the disease with fear, providing information takes place in the hospital, and is usually done by a doctor. The study showed that in Poland access to psychologists in children's wards is insufficient, while leisure time during treatment is organised satisfactorily.

Conclusions: Paediatric care should be expanded to include an element of education for both the patients themselves in the context of reducing stress associated with the disease and parents in the context of contact with the sick child and providing information about the disease entity. It is necessary to increase the availability of psychologists, not only for children, but also among parents. There is a necessity to separate special zones for conversations requiring intimacy. It is important to prepare new solutions.
\end{abstract}

\section{Streszczenie}

Wprowadzenie: Podczas hospitalizacji dziecko przebywa w nieznanym środowisku, co wiąże się z dyskomfortem, strachem i bólem. Trwa nieustanny postęp w dziedzinie poprawy komfortu psychicznego leczonych dzieci poprzez dostosowanie wyglądu placówek, zwiększenie dostępności psychologów oraz edukację rodziców i pacjentów.

Cel pracy: Badanie ma na celu porównanie perspektyw trzech podmiotów - personelu medycznego, rodziców i dzieci w zakresie hospitalizacji pacjentów pediatrycznych ze szczególnym uwzględnieniem opieki psychologicznej.

Materiał i metody: Ankietę składającą się z 12 pytań przeprowadzono wśród 405 respondentów, których podzielono na 3 grupy badawcze i 3 podgrupy w subpopulacji dzieci. Badanie wykonano na oddziałach pediatrycznych o różnym stopniu referencyjności na terenie Polski. Otrzymany materiał poddano szczegółowej analizie statystycznej.

Wyniki: Najczęstszą odpowiedzią we wszystkich grupach była ta, że dzieci reagują strachem na informacje o chorobie, udzielanie informacji odbywa się w szpitalu i zwykle jest wykonywane przez lekarza. Badanie wykazało, że w Polsce dostęp do psychologów na oddziałach dziecięcych jest niewystarczający, a czas wolny w trakcie leczenia jest zorganizowany w stopniu zadowalającym. Przekazywane informacje są przystępne, a choroba ma niewielki wpływ na socjalizację - utrzymywany kontakt z rówieśnikami w placówce jest zadowalający. 
Wnioski: Należy rozszerzyć zakres opieki tak, aby obejmował element edukacji pacjentów w zakresie zmniejszania stresu związanego z chorobą i rodziców w zakresie kontaktu z chorym dzieckiem oraz dostarczania informacji o chorobie. Konieczne jest zwiększenie dostępu do psychologów, nie tylko dla dzieci, lecz także rodziców. Należy wydzielić specjalne strefy do przeprowadzania rozmów wymagających intymności. Ważne jest, aby przygotować nowe rozwiązania, które wpłyną na komfort psychiczny hospitalizowanych dzieci.

\section{Introduction}

There is a worldwide tendency to raise the quality of services in each area of the economy. The increase in competitiveness, the development of technology, and modern techniques of advertisement and sales set higher and higher demands on the management. This also applies to the healthcare sector, which in particular is characterised by high dynamics of technological progress and the use of improvements in the field of information technology (IT) [1].

It is most visible in the context of the private entities competing for acquisition of the patients. Adults using the tools available on the Internet, based on past experience or on the opinion of family or acquaintances, select the place where they want to be treated, diagnosed, or have routine follow-up visits [2].

Regarding children, the decision about the choice of doctor or institution is made in the overwhelming majority of cases by the parent, often without consulting the paediatric patient him/herself.

During hospitalisation the child often finds him/ herself for the first time in an unfamiliar environment and is forced to adjust to the new situation, which can be a difficult experience [3]. In the case of a short-term one-time stay the problem is not so significant. Another group are chronically treated patients whose hospitalisations are frequent and/or long. An additional factor exacerbating the problem is the passive role that patients themselves play in the treatment process, because they are often overlooked in the information flow that reaches only the parent [4].

Children's wards in most of the cases create an opportunity for children to contact a psychologist, find a place to play, and their appearance is supposed to evoke positive emotions. However, this is not a common standard present in every ward in Poland and Europe.

Table 1. Study groups (source - own study)

\begin{tabular}{|lr|}
\hline Group & \multicolumn{1}{c|}{ Respondents } \\
II & Medical staff of the paediatric wards \\
\hline III: & Parents of paediatric patients \\
\hline IIIb & Paediatric patients \\
\hline IIIc & Patients aged $8-11$ \\
\hline
\end{tabular}

The well-being of children who stay in hospitals depends on many factors, including age, family situation, pre-illness mental state, general health condition, as well as the quality of care - in particular the accompanying psychological care, which is very important in the context of increased risk of mental disorders in chronically hospitalised paediatric patients [5].

The doctor's approach to the young patient is an extremely important aspect and, above all, providing information about the disease and the procedures performed in an understandable way. The role of psychologists is a substantial issue, not only in the context of observation and diagnosis but also in the field of preventive care and measures [6].

Care by a medical entity should also cover the parents of hospitalised children, who are exposed to a great deal of stress during a paediatric patient's stay in hospital [7, 8].

An integrated, comprehensive model of psychological care for patients brings only benefits, not only for the patient him/herself, but also on a wider scale - for the entire healthcare system [9].

\section{Aim of the research}

The aim of the study was to compare the perspective of three entities - doctors and nurses (staff), parents and children, in the context of hospitalisation of patients: their degree of awareness (learning about the process of providing information about a disease to a child) and assessment of the conditions of stay in a treatment facility, especially in terms of psychological care. The study was conducted in children's wards in hospitals with varying degrees of reference. These were not the only children's hospitals, offering a complex, interdisciplinary approach to the patient [10].

\section{Material and methods}

A total of 405 respondents, divided into three study groups (Table 1), participated in the study, who answered 12 questions in a single-choice survey.

The study was carried out in paediatric wards of hospitals (clinical, poviat, and voivodship) in Poland, where patients were chronically treated, especially those at risk of mental and behavioural disorders. The completion of surveys covered the period from January 2017 to August 2018. Each time, permission was sought to conduct the study after prior consultation with decision-making people. The obtained material was subjected to statistical analysis. 


\section{Results}

In total, 405 respondents took part in the survey. The study sample was divided into five groups depending on the role in the facility. In the case of paediatric patients, a breakdown was also made according to the age of the respondents. Table 2 illustrates the size of each group.

The subjects were asked 12 questions in turn. The shape of the questions was adapted for each of the examined groups.

The first three questions $(\mathrm{A}, \mathrm{B}, \mathrm{C})$ related to the process of passing on information about the disease to the child and the conditions in which it took place.

The answers to the remaining questions were given a five-grade gradation, with 1 being the lowest grade and 5 being the highest. Table 3 presents the content of the questionnaire and the most frequently chosen answers:

1. Does the facility provide the child with adequate psychological care?

The surveyed ward employees and parents were asked if the hospitalised child had adequate psychological care. Children in three age groups were asked if they had the opportunity to meet a psychologist and whether he/she helped explain the reason for hospitalisation and passed on the information about the disease.

A total of 148 healthcare workers most often responded that children staying in the ward were provided with psychological care, which they assessed at a good level. The average answer score was 3.35.
Table 2. Size of the group (source - own study)

\begin{tabular}{|lcc|}
\hline Group & Size $(n)$ & Size $(n \%)$ \\
Medical staff & 148 & 36.54 \\
Patient's parent & 120 & 29.63 \\
Patient 8-11 y.o. & 38 & 9.38 \\
Patient 12-15 y.o. & 31 & 7.66 \\
Patient 16-18 y.o. & 68 & 16.79 \\
Sum & 405 & 100 \\
\hline
\end{tabular}

Parents (120), when answering the same question, most often answered that they rated the offered psychological assistance as sufficient. The average response was lower than in group 1, at 3.05. In the group of children, divided by age, the most common answer was that they did not have the opportunity to work with a psychologist. The average answer differed in individual groups: for the youngest children $(n=38)$ the average was 2.02; in the group of older children $(n=31)-2.09$; while in the group of the eldest children $(n=68)-1.91$.

2 . To what extent are the parents prepared to talk to their child about the disease?

The study was also conducted in the scope of parents' preparedness to talk to children about the disease. In the group of healthcare personnel the most common answer was: "parents are prepared sufficiently" (average 2.75). Parents, when assessing their preparedness, most often also described it

Table 3. The most common responses among the respondents (source - own study)

\begin{tabular}{|c|c|}
\hline Question's content & The most common response \\
\hline A. How do children react to information about the disease? & With fear (58.52\%) \\
\hline B. Who passes on the information about the disease to the child? & Doctor (64.19\%) \\
\hline C. Where is passing on the information carried out? & In the facility (77.28\%) \\
\hline $\begin{array}{l}\text { 1. Does the facility provide the child with adequate psychological } \\
\text { care? }\end{array}$ & No $(33.83 \%)$ \\
\hline $\begin{array}{l}\text { 2. To what extent are the child's parents prepared to talk to him/her } \\
\text { about the disease? }\end{array}$ & They are prepared at a good level (30.86\%) \\
\hline 3. To what extent is the child aware of its own illness? & It is aware at a sufficient level (28.64) \\
\hline $\begin{array}{l}\text { 4. To what extent does the facility organise free time for the child } \\
\text { during treatment? }\end{array}$ & It organises at the sufficient level (33.58\%) \\
\hline $\begin{array}{l}\text { 5. How do you assess the accessibility of information about illness } \\
\text { passed on to the child? }\end{array}$ & It is accessible at a good level (35.31\%) \\
\hline $\begin{array}{l}\text { 6. To what extent does the disease affect the socialisation of the } \\
\text { child? }\end{array}$ & It has little influence (39.51\%) \\
\hline 7. At what level do children keep in touch with peers in the facility? & They keep sufficient contact (44.20\%) \\
\hline 8. How do you assess the mental state of children? & Sufficient (45.19\%) \\
\hline $\begin{array}{l}\text { 9. In your opinion, is mental comfort (including social needs and } \\
\text { organisation of free time) guaranteed? }\end{array}$ & Yes, at a sufficient level (29.63\%) \\
\hline
\end{tabular}


as sufficient (average 2.92). Children answered on the subject as above, to the question about parental involvement in the conversation about the disease and its extent. In the group of youngest patients, the median response was 3.5 (the most common answers were: "they talked to me a little about it" and "they talked to me a lot about it" (average 3.39). Older children described the preparedness of parents as good (average 3.67), the same as the oldest children.

3. The child's awareness of the disease is an extremely important issue, both in the context of the healing process and mental state.

Another question directed to doctors and nurses as well as parents of hospitalised children concerned the assessment of awareness of their charges. According to the majority, young patients were sufficiently aware (average 2.92 and 3.22 , respectively). The group of children were asked to rate their knowledge about the disease that affected them. In the subgroup of the youngest children, the respondents most often admitted that they knew little about their disease. In the two groups of older subjects they declared that they knew something about the illness (more than little, less than a lot).

4. The authors of the study also pondered on how children spend their free time in treatment facilities. A question was asked about the extent to which the ward organised children's free time during hospitalisation. Staff admitted they organised such activities but to a low degree (average 2.44). The parents rated it worse - most also responded in the same way as the employees surveyed, while the average grade was lower, at 2.16.

Children, regardless of age, most often answered that there was one adequately equipped play area in the hospital.

5. Accessibility of the information provided, often requiring specialised language and the introduction of new, previously unknown terminology, is problematic for doctors as well as parents and children. The surveyed staff members mostly declared that the knowledge they provided was good when it came to accessibility. The parents admitted the same, despite the fact that the average value was slightly lower $(3.63 ; 3.45)$. The youngest children expressed a different opinion - they declared little understanding of the content passed on to them. The elders recognised accessibility as good.

6. The disease affects the physical and mental discomfort of hospitalised children. In itself, the stay in the hospital is an undesirable situation, which is often a very negative experience [3]. Research indicates that it also has an impact on the socialisation of children [11].

In the survey it was asked to what extent illness and hospitalisation affected patients' socialisation. According to the surveyed staff members, it had a little impact. They had the same opinion as parents. The children believed that it had no effect - they did not observe changes in interpersonal relations since the beginning of illness.

7. To better understand the issue of socialisation, the question about the level of contact between a child and his/her peers was asked. The answers showed that hospitalisation and the inconveniences related to it did not prevent young patients from maintaining good contact. In all study groups, this level was most often described as satisfactory. Among the groups of children, the highest median was found in the second subgroup, while the highest median in all groups studied was found among the physicians.

8. How can we assess the overall state of mind of a child being looked after by ward staff?

In the group of doctors and parents, the second quartile described it as "good" (average 2.56 and 2.61, respectively). Hospitalised children assessed their well-being worse than did staff and parents. Most often they declared their mental state as "average". On average, the eldest children rate it the worst.

9. The last question concerned subjective assessment of the provision by the medical facility of psychological comfort, taking into account the needs of socialising, fun, and fulfilling free time for the child. The median response from doctors (i.e. 3) means satisfactory. The parents judged it worse, indicating that the assurance deserves a low rating (average of about 2.5). This is the strictest assessment among all subgroups examined. The responses, subjected to the study is usually a note that corresponds to the doctors' assessment.

\section{Discussion}

The care of psychologists is a very important factor affecting the welfare and well-being of hospitalised patients $[12,13]$. Their work is an integral part of therapy in children who endure long-term hospitalisation caused by illnesses. Its inclusion in primary paediatric care is an element that brings significant benefits to patients [14]. The study indicates the presence of psychologists in the process of treating patients in paediatric hospitals in Poland. However, there are differences in the assessment of the availability and quality of work of specialists in this field. It is rated best by doctors and hospital staff, worse by parents, while children - patients who participated in the study - most often did not have the opportunity to undergo full therapy with a psychologist during hospitalisation. Those of them who underwent therapy rated this cooperation worse than did other study groups. This may be due to the reasons for admission to hospital, length of stay, and the nature of the disease.

It is extremely important and noteworthy that parents and medical staff with no relevant education in child psychology are responsible for providing the child with information about the disease and 
for answering numerous questions. In the context of parents' preparedness for such conversations, doctors and staff describe them as "satisfactory". This assessment is rooted in the lack of an adequate preparatory process for parents of paediatric patients that would allow them to acquire the necessary skills when providing information about the disease to the child. This shows the need for psychological care not only for paediatric patients themselves, but also for their parents.

At a similar level, parents belonging to this group also assess their own preparation. Children for whom parents are often the greatest authority confirm in the study that the role of their parents is significant and indisputable, assessing their preparation and competences higher than other groups. Objective assessment of knowledge about the disease is not possible, due to their diversity in the population of examined children, complexity, and predisposition to transfer information; however, it seems that substantive conversation with a doctor or psychologist with parents or guardians is important and an indication of the materials from which they can derive reliable information confirmed by research.

Another aspect that is problematic for the respondents is the lack of adequate background in the facilities, in the form of separate zones to conduct talks about the disease with the child. Information often transmitted in the conditions of a hospital room or other unfit space and may not be fully comprehended by the patient. This translates directly into the response of paediatric patients during this process, where the predominant response was fear and withdrawal.

Awareness of the disease is also very important for the mental state of the patients undergoing treatment. Anxiety, arising from the lack of awareness and uncertain future, can be reduced by the supply of essential facts. Children participating in the study admit that they know little about their disease (the least among the youngest). Hope is brought by the recently introduced multimedia systems that partially explain the basic issues of the disease in a graphic and interactive way [15]. Despite the accessibility of the information provided by doctors and hospital staff and parents, there is still a problem of insufficient understanding of the mechanisms of the disease, as well as the process of diagnosis, treatment, convalescence (in the group of the youngest - little understanding of the passed on content) it seems necessary to prepare tools to help children to find themselves in a new situation and prepare for the future.

The socialisation of sick children and their ability to make new friends is a very important topic. Admission to the hospital, often a long stay, and repeated medical activities are often a painful and traumatic experience for paediatric patients. Despite this, children are happy to play in places intended for such activities, which were present in all hospitals where the study was conducted. It is very important that there are zones in each facility that provide the possibility of games and activities as well as the meeting between children staying in the hospital. This enables better, more effective, unforced socialisation. Doctors and parents believe that the disease affects, though only slightly, socialisation of children.

On the other hand, they declare that it has no impact; even more so, they observed no changes in interpersonal relations since the onset of illness. In all groups, children's contact with peers was assessed as satisfactory. Many aspects make up a comprehensive, interdisciplinary assessment of the mental state of the patients in hospital wards, regardless of their age. In the research the physicians, staff, and parents were asked to assess the mental state of their charges. Most described this parameter as "good". Patients classified it as "average", indicating that it is worse than their guardians think. In the subgroup of the oldest children, the worst assessment of mental state occurred at the time of hospitalisation, which may be associated with isolation from the environment, a sense of arrears, limiting social life.

The question summarising the study was the subjective assessment of ensuring comfort for the child by the treatment facility, taking into account the needs of socialisation, play, and leisure activities. Despite the fact that employees of the ward do not organise entertainment for those under their care during hospitalisation, doctors and hospital staff most often responded that they assessed satisfying these needs at a satisfactory level. The children staying in the treatment facility responded just like the medics, which may indicate additional, above-average involvement employees, aimed at providing young patients with greater comfort. Parents who often accompany their children almost all the time during their stay in the hospital assess the subject of the study worse than the other two groups.

The results obtained indicate good conditions of care for the youngest patients in paediatric facilities in Poland. However, there are areas that require in-depth analysis and final preparation of solutions, which help improve the conditions of children's stay in hospitals and improve their well-being. The development of technology and its widespread application creates a lot of opportunities, including in the healthcare sector, so it is worth considering the problems of paediatric patients by creating improvements and easements that improve quality of performed services and care.

\section{Conclusions}

It is necessary to increase the availability of psychologists in children's wards and take measures to increase patients' awareness of the possibility of consultations in this regard. 
Greater emphasis should be placed on parents' and young patients' education and creating opportunities to expand knowledge, e.g. through the availability of brochures, website instructions and books containing reliable information, also based on EBM.

Sick children have no sense of exclusion and limitations in their desire to socialise. Doctors and parents, however, note that the disease affects (though to a small extent) socialisation. Therefore, psychologists should put special emphasis on this issue during the therapy. Paediatric care should be expanded to include an element of education for both the patients themselves in the context of reducing stress associated with the disease and parents in the context of contact with the sick child and providing information about the disease entity. During the stay of children in hospital wards, parents play an important role in their recovery and mental balance, whose active participation in the treatment process is desirable in the context of full recovery of the paediatric patient.

Due to the small amount of research conducted in the direction of psychological care and the conditions of stay of patients in paediatric wards, we believe that attempts should be made to expand the knowledge base on this subject.

\section{Acknowledgments}

We thank Mrs Kamila Kocańda, PhD, for support during our work.

\section{Conflict of interest}

The authors declare no conflict of interest.

\section{References}

1. Dimitri P. Child health technology: shaping the future of paediatrics and child health and improving NHS productivity. Arch Dis Childhood 2019; 104: 184-188.

2. Manzoor A. RFID in Health Care-Building Smart Hospitals for Quality Healthcare. Int J User Driven Healthcare 2016; 6: 21-45.

3. Kodish I. Behavioral health care for children who are medically hospitalized. Pediatr Ann 2018; 47: e323-e327.

4. Shoshani A, Kanat-Maymon Y. Involvement in care in pediatric cancer patients: implications for treatment compliance. Mental health and health-related quality of life. Qual Life Res 2018; 27: 567-575.

5. Doupnik SK, Henry MK, Bae H, Litman J, Turner S, Scharko AM, Feudtner C. Mental health conditions and symptoms in pediatric hospitalizations: a single-center point prevalence study. Acad Pediatr 2017; 17: 184-190.

6. Waszkiewicz AA, Nizio AM. Rola psychologa klinicznego w szpitalu psychiatrycznym. Psychiatr Psychoter 2014; 10: 3-10.

7. Commodari E. Children staying in hospital: a research on psychological stress of caregivers. Ital J Pediatr 2010; 36: 40.

8. Kearney JA, Salley CG, Muriel AC. Standards of psychosocial care for parents of children with cancer. Pediatr Blood Cancer 2015; 62: 632-683.
9. Moser NL, Plante WA, LeLeiko NS, Lobato DJ. Integrating behavioral health service into pediatric gastroenterology: a model of an integrated health care program. Clin Practice Pediatr Psychol 2014; 2: 1-12.

10. Casimir G. Why children's hospitals are unique and so essential. Front Pediatr 2019; 7: 305.

11. Gomes GL, Fernandes MD, Nobrega MM. Hospitalization anxiety in children: conceptual analysis. Brazil J Nursing 2016; 69: 884-889.

12. Robinson JD, Baker J. Psychological consultation and services in a general medical hospital. Professional Psychology 2006; 37: 264-267.

13. Wahass SH. The role of psychologists in health care delivery. J Fam Commun Med 2005; 12: 63-70.

14. Hansel T, Rohrer G, Osofsky J, Osofsky H, Arthur E, Barker C. Integration of mental and behavioral health in pediatric health care clinics. J Public Health Manag Practice 2017; 23: 19-24.

15. Hollis C, Falconer CJ, Martin JL, Whittington C, Stockton S, Glazebrook C, Davies EB. Annual research review: digital health interventions for children and young people with mental health problems - a systematic and meta-review. J Child Psychol Psychiatry 2017; 58: 474-503.

\section{Address for correspondence:}

\section{Krzysztof K. Starszak}

Department of Orthopaedics

Faculty of Medical Sciences in Zabrze

Medical University of Silesia

Trauma Center

Plac Medyków 1, 41-200 Sosnowiec, Poland

Phone: +48 664951441

E-mail: krzysztof.starszak@gmail.com 